\title{
Conservation Tillage Impact on Topsoil and Deep Soil Aggregation and Aggregate Associated Carbon Fractions and Microbial Community Composition in Subtropical India: A Review
}

\author{
Rajendra Kumar ${ }^{1 *}$, R. K. Naresh ${ }^{1}$, Robin Kumar ${ }^{2}$, S. K. Tomar ${ }^{3}$, Amit Kumar ${ }^{4}$, \\ M. Sharath Chandra ${ }^{1}$, Omkar Singh ${ }^{1}$, N. C. Mahajan ${ }^{5}$ and Reenu Kumar ${ }^{1}$ \\ ${ }^{1}$ Department of Agronomy, Sardar Vallabhbhai Patel University of Agriculture \& Technology, \\ Meerut, U.P., India \\ ${ }^{2}$ Department of Soil Science \& Agriculture Chemistry, Narendra Dev University of \\ Agriculture \& Technology, Kumarganj, Ayodhya, U.P., India \\ ${ }^{3}$ K.V.K.Belipur, Gorakhpur, Narendra Dev University of Agriculture \& Technology, \\ Kumarganj, Ayodhya, U.P., India \\ ${ }^{4}$ Department of Agronomy, Chaudhary Charan Singh Haryana Agricultural University-Hisar, \\ Haryana, India \\ ${ }^{5}$ Department of Agronomy, Institute of Agricultural Science, Banaras Hindu University, \\ Varanasi, U. P., India \\ *Corresponding author
}

\section{Keywords}

Tillage system, Soil organic carbon, Microbial biomass, Soil aggregation

Article Info

Accepted: 04 September 2019 Available Online: 10 October 2019
Soil macro-aggregate turnover and micro-aggregate formation: A mechanism for $\mathrm{C}$ sequestration under notillage agriculture had its genesis in attempts to identify and isolate soil organic matter (SOM) fractions that reflect the impacts of climate, soil physiochemical properties and physical disturbance on the soil organic carbon balance. Soil tillage can affect the formation and stability of soil aggregates. The disruption of soil structure weakens soil aggregates to be susceptible to the external forces of water, wind, and traffic instantaneously, and over time. The application of chemical fertilizers (NP) alone did not alter labile C fractions, soil microbial communities and SOC mineralization rate from those observed in the CK treatment. Whereas the use of straw in conjunction with chemical fertilizers (NPS) became an additional labile substrate supply that decreased $\mathrm{C}$ limitation, stimulated growth of all PLFA-related microbial communities, and resulted in 53\% higher cumulative mineralization of $\mathrm{C}$ compared to that of $\mathrm{CK}$. The SOC and its labile fractions explained $78.7 \%$ of the variance of microbial community structure. The degree of soil disturbance and the use of crop residues influence the availability of organic compounds and minerals for the soil biota. This conglomerate of elements can affect population, diversity and activity of the different soil organisms. Besides, soil communities also have an impact on soil physical and chemical conditions. From macro-fauna to micro-fauna, all parts interact and therefore play a role in nutrient cycling and organic matter decomposition. Soil microbial community compositions were changed with straw return. Crop straw return significantly increased total phospholipid fatty acid (PLFA), bacterial biomass and actinomycete biomass by 52,75 and $56 \%$ but had no significant effects on PLFAs as compared to $\mathrm{N}$ treatment. MBC and TOC were the two main factors affecting microbial communities under short-term crop straw return. The labile part of organic carbon has been suggested as a sensitive indicator of changes in soil organic matter. Conservation tillage (NT and S) increased microbial metabolic activities and microbial index in $>0.25$ and $<0.25 \mathrm{~mm}$ aggregates in the $0-5 \mathrm{~cm}$ soil layer. 


\section{Introduction}

Soil is considered the 'skin' of the earth (Oades, 1984) with soil organic carbon (SOC) as the protein that protects the 'skin' (Dou et al., 2011). SOC is a key indicator of soil quality (Bronick and Lal, 2005) is the basis of soil fertility and function (Huang et al., 2012) and is important for cementing substances as part of the formation of soil aggregates. SOC affects the number and distribution of differently sized soil aggregates (Zheng et al., 2011). Soil aggregates are the basic 'cells' of the soil structure and play an important role in improving soil carbon sequestration and fertility (Zhou et al., 2009). Stable soil aggregates not only reduce soil erosion induced SOC loss, but also inhibit microbial and enzymatic decomposition of SOC through coating and isolation effects Humberto and Rattan, 2004; Six et al., 2000). Physical fraction is widely used to study the storage and turnover of soil organic matter (SOC), because it incorporates three levels of analysis by examining three sizes of aggregate. Previous studies have demonstrated that the interaction between soil structure and aggregates determines the quality of the SOC pool. SOC is primarily distributed in waterstable aggregates of larger sizes $(>1 \mathrm{~mm})$ and SOC content increases with aggregate diameter (Six et al., 1998; Liu et al., 2009). The combined application of chemical fertilizer and straw greatly improves SOC accumulation in water-stable aggregates of this size (Zhou and Pan, 2007).

Intensive soil tillage initiates a cascade of events that has been shown to both benefit and impair agricultural productivity.Net losses in soil fertility and soil integrity have led to the development of alternative management strategies that control problems associated with intensive tillage while affording acceptable conditions of seedbed preparation, fertility, and weed control. No-tillage with a large addition of plant biomass to the soil enhances SOC storage. This constitutes an effective way to restore SOC over time (Hok et al., 2015). The SOC may be vertically distributed in deeper soil layers in long-term conservation agriculture in response to high biomass-C inputs from deep-rooting cover crops. Tilling can play an important role in increasing crop yield, thereby improving food security worldwide by making crop growth more successful and controlling competition by weeds (Lal, 2009). However, many studies have demonstrated that intensive tillage deteriorates soil structure and enhance soil erosion (Kladivko, 2001). Specially, mouldboard ploughing may damage the pore continuity and aggregate stability resulting in sediment mobilization, erosion, and surface hardening (Hamza and Anderson, 2005). This effect frequently exposes aggregates to physical disruption (Al-Kaisi et al., 2014). The resulting breaking of aggregates enhances the accessibility of organic matter (OM) to microorganisms, stimulating oxidation and loss of organic matter (Liang et al., 2009). Declines in organic matter are thus usually accompanied by a decrease in the number of water-stable aggregates (Six et al., 1999). Under no tillage, crop residue decomposes at a slower rate, leading to a gradual build-up and increase in soil organic carbon (SOC).

Soil organic matter fractions are the most sensitive way to detect changes in soil tillage over time (Rosset et al., 2016). No-tillage leads to greater carbon stability with a predominance of the humin fraction. Soil tillage and residue management affect the input of organic residues into the soil and, thus, its physicochemical properties, above all aggregate stability (Guimarães et al., 2013). Compared to NT, CT negatively affects soil aggregate stability, which leads to an increased susceptibility to slaking (Paul et al., 2013) and soil erosion (Bertol et al., 2014). The adoption of an NT system improves soil 
aggregation and aggregate stability (Seben Junior et al., 2014). Stable aggregation has frequently been shown to reduce susceptibility to formation of runoff and water erosion (Bertol et al., 2014), depending on clay mineralogy. In addition, fresh residue inputs and active root growth led to more and stronger organic cementing in 2:1 than in $1: 1$ clay minerals in soils (Denef and Six, 2005).

Soil management influences soil microorganisms and soil microbial processes through changes in the quantity and quality of plant residues entering the soil, their seasonal and spatial distribution, the ratio between above-and below-ground inputs, and changes in nutrient inputs (Kandeler et al., 1999). Changes in tillage, residue, and rotation practices induce major shifts in the number and composition of soil fauna and flora, including both pests and beneficial organisms (Andersen, 1999). Microbial communities play an important role in nutrient cycling by mineralizing and decomposing organic material, which are released into the soil as nutrients that are essential for plant growth. These communities can influence nutrient availability by solubilisation, chelation, and oxidation/ reduction processes. In addition, soil microorganisms may affect nutrient uptake and plant growth by the release of growth stimulating or inhibiting substances that influence root physiology and root architecture. It has been suggested that microbial inoculants are promising components for integrated solutions to agroenvironmental problems because inoculants possess the capacity to promote plant growth (Compant et al., 2010) enhance nutrient availability and uptake (Adesemoye and Kloepper, 2009) and improve plant health. No single agricultural practice is sufficient to guarantee the quality of soils. However, changes in microbial communities could be used to predict the effects of soil quality by different environmental and anthropogenic factors. In addition, knowledge on soil microbial processes will provide insight into how agricultural practices such as tillage systems can be better managed to increase soil quality. In this review, we describe and discuss the effects of different tillage practices on microbial metabolic activities, organic $\mathrm{C}$ fractions, and SOC to elucidate the relationship better between soil microbial metabolic diversity and SOC within aggregates in subtropical India.

Soil aggregates are groups of soil particles that bind to each other more strongly than to adjacent particles. The spaces between the aggregates provide pore space for retention and exchange of air and water.

Soil microorganisms excrete substances that act as cementing agents and bind soil particles together. Fungi have filaments, called hyphae, which extend into the soil and tie soil particles together. Roots also excrete sugars into the soil that help bind minerals. Oxides also act as glue and join particles together.

Topsoil is composed of mineral particles, organic matter, water, and air. Organic matter varies in quantity on different soils. The strength of soil structure decreases with the presence of organic matter, creating weak bearing capacities

Only 300 to 1,000 years are required to build an inch of topsoil. The average depth of topsoil is about eight inches, indicating an earth less than about 8,000 years old.

Soil microorganisms exist in large numbers in the soil as long as there is a carbon source for energy.... Soils contain about 8 to 15 tons of bacteria, fungi, protozoa, nematodes, earthworms, and arthropods. See fact sheets on Roles of Soil Bacteria, Fungus, Protozoa, and Nematodes 
Microbial communities are groups of microorganisms that share a common living space. The microbial populations that form the community can interact in different ways, for example as predators and prey or as symbionts.

Fraction scheme to isolate aggregate and aggregate-associated soil organic carbon (SOC) fractions $\mathrm{LF}=$ light fraction; $\mathrm{HF}$ =heavy fraction; $\mathrm{MOM}=$ mineral-associated organic matter; $\mathrm{cPOM}=$ coarse particulate organic matter (POM); fPOM = fine POM; HMP = hexa-meta-phosphate; imMPOM = intra-micro-aggregate POM within macroaggregate; imMMOM = intra-microaggregates MOM within macro-aggregate; imPOM = intra-micro-aggregate POM; imMOM = intra-micro-aggregate MOM [Source: Cheng-Hua et al., 2014]

Song et al., (2016) reported that as compared to conventional tillage, the percentages of $>2$ $\mathrm{mm}$ macroaggregates and water-stable macroaggregates in rice-wheat doubleconservation tillage (zero-tillage and straw incorporation) were increased $17.22 \%$ and $36.38 \%$ in the $0-15 \mathrm{~cm}$ soil layer and $28.93 \%$ and $66.34 \%$ in the $15-30 \mathrm{~cm}$ soil layer, respectively. Zero tillage and straw incorporation also increased the mean weight diameter and stability of the soil aggregates [Fig. $1 \mathrm{a} \& 1 \mathrm{~b}$ ]. In surface soil $(0-15 \mathrm{~cm})$, the maximum proportion of total aggregated carbon was retained with $0.25-0.106 \mathrm{~mm}$ aggregates, and rice-wheat doubleconservation tillage had the greatest ability to hold the organic carbon (33.64 $\mathrm{g} \mathrm{kg}^{-1}$ ). However, different forms occurred at higher levels in the $15-30 \mathrm{~cm}$ soil layer under the conventional tillage [Fig.1c].

Fang et al., (2015) revealed that the cumulative carbon mineralization $\left(\mathrm{C}_{\min }\right.$, $\mathrm{mgCO}_{2}-\mathrm{C} \mathrm{kg}^{-1}$ soil) varied with aggregate size in BF and CF top-soils, and in deep soil, it was higher in larger aggregates than in smaller aggregates in $\mathrm{BF}$, but not $\mathrm{CF}$ [Fig.2a]. The percentage of soil OC mineralized $\left(\mathrm{SOC}_{\min }, \%\right.$ $\mathrm{SOC}$ ) was in general higher in larger aggregates than in smaller aggregates. Meanwhile, $\mathrm{SOC}_{\min }$ was greater in $\mathrm{CF}$ than in $\mathrm{BF}$ at topsoil and deep soil aggregates. In comparison to topsoil, deep soil aggregates generally exhibited a lower $\mathrm{C}_{\min }$, and higher $\mathrm{SOC}_{\min }$ [Fig.2b]. However, deep soil may be more readily decomposed in $\mathrm{CF}$ than in $\mathrm{BF}$, potentially as a result of a higher dead fine root biomass, since fresh carbon may accelerate soil OC decomposition (Fontaine et al., 2007). To sum up, organic matter decomposition and OC transportation from topsoil to deep soil might be the dominant processes influencing deep soil OC in these soils. von Lützow et al., (2007) reported that the turnover time of $\mathrm{OC}$ in macro-aggregates and micro-aggregates were $15-50$ years and as long as $100-300$ years using ${ }^{13} \mathrm{C}$ natural abundance method, respectively, which indicates that micro-aggregates are more effective for decreasing OC mineralization relative to macro-aggregates. Moreover, acid hydrolysis process in soil was considered to remove easily decomposable protein and polysaccharide material leaving behind chemical recalcitrant structures which may be able to isolate deeper soil $\mathrm{C}$ with long-term stability due to the evidence that the $\mathrm{C}$ isolated by acid hydrolysis from deeper soil was several hundred or thousand years older than bulk soil. The reforestation tree species appeared to be an important determinant of OC stability through the influence on soil nutrient and its stoichiometric ratio [30] and $\mathrm{BF}$ might be more efficient in $\mathrm{OC}$ conservation than $\mathrm{CF}$ at the sites we studied [Fig.2c] and deep soils may have lower OC stability than topsoil.

Zhang-liu et al., (2013) showed that NT and RT treatments significantly increased the proportion of macro-aggregate fractions 
(>2000 $\mu \mathrm{m}$ and 250-2000 $\mu \mathrm{m}$ ) compared with the MP-R and MP+R treatments [Fig.3a]. For the $0-5 \mathrm{~cm}$ depth, the total amount of macroaggregate fractions $(>250 \mu \mathrm{m})$ was increased by $65 \%$ in NT and $32 \%$ in RT relative to the $\mathrm{MP}+\mathrm{R}$. Averaged across all depths, the macroaggregate fraction followed the order of NT (0.39) > RT (0.30) > MP+R (0.25) $=\mathrm{MP}-\mathrm{R}$ (0.24). Accordingly, the proportion of microaggregate fraction $(53-250 \mu \mathrm{m})$ was increased with the intensity of soil disturbance [Fig.3a]. In the $0-5$ and $5-10 \mathrm{~cm}$ depths, NT and RT had significantly higher total soil $\mathrm{C}$ concentration than that of MP-Rand MP+R in all aggregate size fractions [Fig.3b].However, in the 10$20 \mathrm{~cm}$ depth, conservation tillage system reduced total $\mathrm{C}$ concentration in the macroaggregate fraction $(>250 \mu \mathrm{m})$ but not in the micro-aggregate and silt plus clay fractions. The greatest change in aggregate $\mathrm{C}$ appeared in the large macro-aggregate fractions where aggregate-associated $\mathrm{C}$ concentration decreased with depth [Fig.3b]. In the $0-5 \mathrm{~cm}$ depth, the $>2000 \mu \mathrm{m}$ fraction had the largest $\mathrm{C}$ concentration under NT, whereas the $<53 \mu \mathrm{m}$ fraction had the lowest $\mathrm{C}$ concentration under the MP-R treatment. Similar trend was also observed in the $>2000 \mu \mathrm{m}$ and $25-2000 \mu \mathrm{m}$ fractions (23 vs. $24 \mathrm{~g} \mathrm{C} \mathrm{kg}^{-1}$ aggregates) in the $5-10 \mathrm{~cm}$ depth. The large macro-aggregate $(>2000 \mu \mathrm{m})$ had relatively lower C concentration than that in the $>250-2000 \mu \mathrm{m}$ fraction in the $10-20 \mathrm{~cm}$ depth. Averaged across soil depths, all aggregate size fractions had 6-9\% higher total soil $\mathrm{C}$ concentration in $\mathrm{NT}$ and $\mathrm{RT}$ than in $\mathrm{MP}-\mathrm{R}$ and $\mathrm{MP}+\mathrm{R}$, except for the 53-250 $\mu \mathrm{m}$ fraction. Again mouldboard plough showed slightly higher soil $\mathrm{C}$ concentration than the conservation tillage systems in the 53-250 $\mu \mathrm{m}$ fraction [Fig.3b].

Tillage systems also affected the distribution of total $\mathrm{C}$ stocks across the aggregate fractions [Fig.3c]. In the $0-5$ and $5-10 \mathrm{~cm}$ depths, total soil C stocks within the $>2000$ and $250-2000$ $\mu \mathrm{m}$ fractions followed the order of NT $>\mathrm{RT}>$
$\mathrm{MP}+\mathrm{R}=\mathrm{MP}-\mathrm{R}$. Considering the $>2000 \mu \mathrm{m}$ fraction in the $0-5 \mathrm{~cm}$ depth, soil $\mathrm{C}$ stocks were $155 \%$ and $79 \%$ higher in NT and RT than that in the MP treatments. Across the aggregate fractions, in the $0-5 \mathrm{~cm}$ depth, the small macro-aggregate under NT had $21 \%$ and $171 \%$ moretotal $\mathrm{C}$ than $\mathrm{RT}$ and $\mathrm{MP}$, respectively. Similar results were observed in the $5-10 \mathrm{~cm}$ depth. Total $\mathrm{C}$ stored in macroaggregates $(>250 \mu \mathrm{m})$ was $73 \%$ higher in RT and $33 \%$ higher in NT compared to the average across both MP treatments. In the 10$20 \mathrm{~cm}$ depth, soil $\mathrm{C}$ stored in the $>2000$, and $250-2000 \mu \mathrm{m}$ fractions did not differ among the RT, NT and MP+R treatments [Fig.3c]. The largest $\mathrm{C}$ stock occurred in the 53-250 $\mu \mathrm{m}$ fraction, following the order of $\mathrm{MP}+\mathrm{R}>\mathrm{RT}>$ MP-R > NT [Fig.3c].

Ravindran and Yang, (2015) also found that the $\mathrm{C}_{\text {mic }}$ and $\mathrm{N}_{\text {mic }}$ were highest in the surface soil and declined with the soil depth. These were also highest in spruce soils, followed by in hemlock soils, and were lowest in grassland soils. The organic layer had the highest $\mathrm{C}_{\text {mic }}$ and $\mathrm{N}_{\text {mic }}$, and the values decreased significantly with soil depth. The maximal $\mathrm{C}_{\text {mic }}$ and $\mathrm{N}_{\text {mic }}$ were obtained in the spring season and the minimal values in the winter season. The $\mathrm{C}_{\text {mic }} / \mathrm{C}_{\text {org }}, \mathrm{N}_{\text {mic }} / \mathrm{N}_{\text {tot }}$, and $\mathrm{C}_{\text {mic }} / \mathrm{N}_{\text {mic }}$ ratios increased with soil depth [Fig.4a]. The higher $\mathrm{C}_{\text {mic }}$ and $\mathrm{N}_{\text {mic }}$ in the surface soil than in the deeper layers were due to their positive correlations with organic matter content and oxygen availability (Idol et al., 2002). $\mathrm{C}_{\text {mic }}$ and $\mathrm{N}_{\text {mic }}$ had significantly positive correlations with total organic carbon $\left(\mathrm{C}_{\text {org }}\right)$ and $\mathrm{N}_{\text {tot }}$. Contributions of $\mathrm{C}_{\text {mic }}$ and $\mathrm{N}_{\text {mic }}$, respectively, to $\mathrm{C}_{\text {org }}$ and $\mathrm{N}_{\text {tot }}$ indicated that the microbial biomass was immobilized more in spruce and hemlock soils than in grassland soils [Fig.4b]. Microbial populations of the tested vegetation types decreased with increasing soil depth. Bacterial population was highest among the microbial populations. The ratios of cellulolytic microbes to totalmicrobial 
populations in organic layers were high due to the roles of carbon cycle. A high $\mathrm{C}_{\text {mic }} / \mathrm{N}_{\text {mic }}$ ratio indicates that the microbial biomass contains a high proportion of fungi, whereas a low value suggests that bacteria predominate in the microbial populations (Joergensen et al., 1995). Paul and Clark, (1996) reported that bacterial dominant soil had a $\mathrm{C} / \mathrm{N}$ ratio between 3 and 5 , whereas a $\mathrm{C} / \mathrm{N}$ ratio between 10 and 15 indicated the dominancy of fungi. In the present study, the $\mathrm{Cmic} / \mathrm{Nmic}$ ratios of spruce, hemlock, and grassland soils were 5.2e6.5, 4.8e6.6, and 4.1e5.6, respectively, showing the dominancy of bacteria.

Al-Kaisi and Yin, (2005) revealed that macroaggregate stability as a function of time shows a different trend for the same tillage systems over time [Fig.4c]. However, stable micro and macro-aggregate ranged as follows: greater in NT, ST, and CP compared with MP and DR. The percentage of stable microaggregates observed between 12 and 240 minutes for tillage treatments was in the following order: $\mathrm{NT}>\mathrm{ST}>\mathrm{CP}>\mathrm{DR}>\mathrm{MP}$. The higher percentage of stable micro-aggregates observed in the NT and ST treatments compared with CP and DP is consistent with the findings of Ouattara et al., (2008), where macro-aggregate stability with reduced tillage was $87 \%$ and $26 \%$ higher in sandy loam soils.

Meenakshi (2016) revealed that under conventional tillage, the organic carbon content in the surface $0-15 \mathrm{~cm}$ soil depth was $0.44,0.51$ and $0.60 \%$ which was increased to $0.60,0.62$ and $0.70 \%$ under zero tillage practice in sandy loam, loam and clay loam soil [Fig.5a]. In all the three soils, the organic carbon decreased significantly with depth under both the tillage practices. Under conventional tillage, the amount of organic carbon observed in $0-15 \mathrm{~cm}$ found to decrease abruptly in 15-30 $\mathrm{cm}$ soil depth as compared to the decrease under zero tillage practice in all the soils. Long term ZT practice in wheat increased the organic carbon content significantly as compared to CT in different depths of all the soils. As expected, the higher amount of organic carbon was observed in relatively heavier textured soil viz. clay loam $>$ loam > sandy loam at both the depths [Fig.5a].

Moreover, under conventional tillage, the light fraction carbon, in the surface $0-15 \mathrm{~cm}$ soil depth was $0.29,0.49$ and $0.58 \mathrm{~g} / \mathrm{kg}$ which increased to $0.43,0.62$ and $1.01 \mathrm{~g} / \mathrm{kg}$ under zero tillage practice

in sandy loam, loam and clay loam soil [Fig.5b]. The heavy fraction carbon in the surface $0-15 \mathrm{~cm}$ soil layer was 3.8, 4.2 and 4.9 $\mathrm{g} / \mathrm{kg}$ which decreased to $2.0,2.2$ and $2.6 \mathrm{~g} / \mathrm{kg}$ in $15-30 \mathrm{~cm}$ soil layer in sandy loam, loam and clay loam, respectively. The heavy fraction carbon was highest in the surface layer in all the three soils and decreased with depth under both tillage treatments. The zero tillage resulted in an increase in heavy fraction carbon at both the depth. In the surface 0-15 $\mathrm{cm}$, it increased the heavy fraction carbon significantly from 3.8 to $4.9,4.2$ to 4.9 and 4.9 to $5.1 \mathrm{~g} / \mathrm{kg}$ and in $15-30 \mathrm{~cm}$ soil depth from 2.0 to $2.9,2.2$ to 3.4 and 2.6 to $3.9 \mathrm{~g} / \mathrm{kg}$ in sandy loam, loam and clay loam [Fig.5b]. Relatively higher amount of heavy fraction carbon was observed in heavier textured soil at both the depths. Liang et al., (1998) reported that ratios of $\mathrm{LF}$ of $\mathrm{C}$ and SOC were greater in light-textured soils than in finetextured soils. $\mathrm{LF}$ of $\mathrm{C}$ is directly proportional to sand content. The lower disturbance in ZT systems can promote the interaction between clays and slower decomposing $\mathrm{C}$ inputs to form soil aggregates. But the DOC content was lowest among all fractions followed by MBC and LFC, and highest amount was of HFC in case of all the three texturally different soils at both $0-15$ and $15-30 \mathrm{~cm}$ soil depths [Fig.5b]. The higher amounts of different fractions were observed in relatively heavier 
textured soil, and under ZT treatment as compared to CT.

Al-Kaisi and Yin, (2005) reported that the continuous decline in SOC content with increase tillage intensity at the top $15 \mathrm{~cm}(6$ in) depth ranked as follows with NT showing the highest SOC content followed by $\mathrm{CP}, \mathrm{ST}$, DR, and MP [Fig.5c]. SOC content, especially in conventionally tilled soils, resulted in less stable aggregates compared with that for NT soils. However, the only significant increase in SOC content at the top $15 \mathrm{~cm}$ (6 in) was observed with NT as compared to the baseline, but STN content was significantly greater than that for the baseline for all tillage systems [Fig.5c]. Soil tillage manipulates soil nutrient storage and release with rapid mineralization of SOM and the potential loss of SOC and STN from the soil (Chivenge, 2007). These changes in the short term can be insignificant, yet SOC content for NT soil aggregates increased over time, consistent with the findings of Sainju et al., (2008). Stable macroaggregates are enriched in new SOC compared with unstable macro-aggregates (Gale et al., 2000), especially in relatively undisturbed systems like NT, where new root-derived intra-aggregate particulate organic matter is important in stabilizing small macroaggregates.

Xin et al., (2015) revealed that the tillage treatments significantly influenced soil aggregate stability and OC distribution. Higher MWD and GMD were observed in 2TS, 4TS and NTS as compared to T. With increasing soil depth, the amount of macroaggregates and MWD and GMD values were increased, while the proportions of microaggregates and the silt + clay fraction were declined [Fig. 6 a \& 6b].

Accordingly, the average proportions of micro-aggregates and the silt + clay fraction were reduced by 15 and $23 \%$, respectively. In the 5-10 $\mathrm{cm}$ depth, the mass proportions of macro-aggregates of 2TS, 4TS and NTS were increased by 12,11 and $13 \%$, respectively, but there were no significant differences between $\mathrm{T}$ and TS. In the $10-20 \mathrm{~cm}$ depth, the proportions of macro-aggregates in 4TS and NTS were increased by $8 \%$ compared to $4 \mathrm{~T}$ and NT. Across all soil depths, 2TS, 4TS and NTS had greater proportions of macroaggregates than $\mathrm{T}$, and this trend was declined with soil depth [Fig.6a]. In the $0-5 \mathrm{~cm}$ layer, compared with $\mathrm{T}$, values of MWD under 4T and NT were increased by 41 and $68 \%$, respectively. Values of MWD under NT in the 5-10 and 10-20 cm depths were increased by 41 and $28 \%$ as compared to that under T. The highest GMD value appeared in NTS, while the lowest appeared in T across all soil depths. Additionally, residue retention had pronounced positive effects on MWD and GMD. The average MWD values among crop residue treatments were 30,15 and $14 \%$ higher than the corresponding treatments without crop residues in the $0-5,5-10$, and 10-20 cm depths [Fig.6b].

The OC concentrations in different aggregate fractions at all soil depths followed the order of macro-aggregates $>$ micro-aggregates $>$ silt + clay fraction. In the $0-5 \mathrm{~cm}$ soil layer, concentrations of macro-aggregate associated OC in 2TS, 4TS and NTS were 14, 56 and $83 \%$ higher than for $\mathrm{T}$, whereas $\mathrm{T}$ had the greatest concentration of OC associated with the silt + clay fraction in the 10-20 cm layer. Soil OC concentrations under 4TS and NTS were significantly higher than that of $\mathrm{T}$ in the 0-10 cm layer. Residue retention promoted formation of macro-aggregates, increased macro-aggregate-associated OC concentrations and thus increased total soil OC stock [Fig.6c]. In the 0-5, 5-10 and 10-20 cm depths, treatments with crop residues had higher macro-aggregate-associated OC concentrations compared to treatments without residues. In the $0-5 \mathrm{~cm}$ depth, comparing with 
that of $\mathrm{T}$, macro-aggregate- associated OC concentrations under 2TS, 4TS and NTS were increased by 14,56 and $83 \%$, respectively. The greatest increase of micro-aggregateassociated OC concentration among treatments with residue retention was in the 0 $5 \mathrm{~cm}$, where OC under 4TS and NTS were 34 and $11 \%$ higher compared to that of $4 \mathrm{~T}$ and NT, respectively. However, in the $10-20 \mathrm{~cm}$, residue retention reduced $\mathrm{OC}$ concentration by $42 \%$ in the silt + clay fraction [Fig.6c].

Wang et al., (2018) reported that straw amendments at $1-5 \%$ increased the relative abundance of Firmicutes from $41 \%$ in control to $54-77 \%$, while decreased the abundances of other bacterial communities. For example, relative abundance of Proteobacteria at day 15 decreased from $18 \%$ to $7.2-13 \%$ in soil. Similarly, straw amendments at $1-5 \%$ increased the abundance of Firmicutes from $28 \%$ to $60-71 \%$, while decreased the abundances of other bacterial communities (e.g., Proteobacteria, $18 \%$ to $11-13 \%$ ). The increases in the abundance of Firmicutes in both soils with straw amendments were also observed at days 30 and 60. However, at day 60 , the difference in the abundance of Firmicutes between straw application rates 1$5 \%$ was insignificant [Fig.7a].

Six and Paustian, (2014) reported that the better assessments of aggregate stability must rely on the measurement of different aggregate distributions due to different levels of energy imposed on the soil and can be related to different soil processes [Fig.7b]. Nonetheless, with the "viewing" techniques, we can focus on the soil morphology and moreover, it is the ideal method to study the small-scale biogeography of microorganisms, e.g., what does the local microhabitat for bacteria and fungi look like? And the inherent small-scale soil variability can be assessed [Fig.7b]. The micro-aggregate-within- macro-aggregate fraction as a diagnostic for SOM changes induced by management across many soil types and climate regimes. However, there are still many soil types and environments that need to be considered before we can state with full confidence that the micro-aggregate within- macro-aggregate fraction is a highly accurate and broadly applicable diagnostic measure for total SOC changes in response to changes in management practices in terrestrial ecosystems. However, if the micro-aggregatewithin-macro-aggregate fraction is found to be truly diagnostic across most soil types and environments, it would be of enormous significance and lead to a rapid and better understanding of how management impacts SOM dynamics and $\mathrm{C}$ sequestration in the terrestrial biosphere.

Li et al., (2018) observed that the effects of fertilization on soil labile organic $\mathrm{C}$ showed a similar trend to total SOC. The contents of DOC, LFOC, and MBC were respectively 264\%, 108\%, and 102\% higher after NPSM application, and respectively 57\%, 82\% and $38 \%$ higher after NPS application than compared with those of $\mathrm{CK}$ [Fig.7c]. The $\mathrm{C} / \mathrm{N}$ ratio of bulk soil was constant across all fertilization treatments, but $\mathrm{C} / \mathrm{N}$ ratio of labile organic $\mathrm{C}$ factions had differential responses to the different treatments [Fig.7c].Ratios of DOC/DON and LFOC/LFN were lower in treatments with additions of exogenous organic amendment and chemical fertilizers than in the control.

Li et al., (2018) also found that the NPSM and NPS fertilization treatments had significantly greater abundances of all microbial groups considered (i.e. G+, G-, actinomycetes, saprophytic fungi and AMF), however, we found no further increases from NPS to NPSM [Fig.8a]. Compared with CK, NPSM and NPS treatments caused greater measures of $\mathrm{G}+$ and G- biomarkers by $107 \pm 160 \%$ and 106-110\%, and greater measures of actinomycetes by 66$86 \%$. The NPSM and NPS treatments were 
also greater in abundances of fungal communities, the saprophytic fungi were greater by $123-135 \%$ and AMF was greater by 88-96\%. The G+/G- ratio was higher under NPSM treatment compared to other treatments, indicating that NPSM fertilization had changed soil microbial communities.

Kushwaha et al., (2000) revealed that the amount of MBC ranged widely: CT-R 214264, CT+R 299-401, MT-R 241-295, MT $\$ R$ 368-503, ZT-R 243-317, and ZT $\$$ R 283-343 $\mu \mathrm{gg}^{-1}$ dry soil [Fig.8b] suggesting significant role of residue retention and tillage practices on the levels of MBC in agro-ecosystems. However, treatments, MBN ranged: CT-R 20.3-27.1, CT $₫ \mathrm{R}$ 32.8-44.0, MT-R 23.7-31.2, $\mathrm{MT}+\mathrm{R}$ 38.2-59.7, ZT-R 24.1- 29.6, and ZT $\$ \mathrm{R}$ 27.0-35.2 $\mu \mathrm{gg}^{-1}$ dry soil [Fig.8c]. The amount of MBN increased significantly in the residue retained plots compared to the residue removed plots.

Residue retention increased $(60 \%$ over control) the level of $\mathrm{MBN}$ in conventional tillage treatment $(\mathrm{CT}+\mathrm{R})$. The combined effect of residue retention and minimum tillage (MT+R) considerably increased (104\% over control) the level of soil MBN. However, the surface application of retained residue with zero tillage $(\mathrm{ZT}+\mathrm{R})$ increased the level of MBN only by $29 \%$ over control. The effect of tillage reduction alone (MT-R, ZT-R) on the level of MBN was less marked (11-16\% increase over control). Singh and Singh (1993) reported 77 and $84 \%$ increase in the levels of MBN under straw + fertilizer and straw treatments, respectively, in a rice based agroecosystems

Zang et al., (2017) observed that the Miscanthus cultivation and the input of $\mathrm{C}_{4}$ derived $\mathrm{C}$ strongly increased $\sigma^{13} \mathrm{C}$ values at all depths relative to the reference grassland. The $6{ }^{13} \mathrm{C}$ values increased with depth from -28.4 to $-24.8 \%$ in the grassland soil, but decreased from -23 to $-24 \%$ (9 years) and from -18 to $24 \%$ (21 years) under Miscanthus. The $\sigma^{13} \mathrm{C}$ values increased strongly from 9 to 21 years after Miscanthus planting, especially in the top $50 \mathrm{~cm}$ of soil [Fig.9a]. However, SOM significantly increased by $30-80 \%$ from 9 to 21 years under Miscanthus at 0-10 and 30-60 cm depths [Fig.9a].

Down the soil profile, the SOM contents declined gradually from the top 10 to $90-100$ $\mathrm{cm}$ depth [Fig.9a]. The $\mathrm{C}$ stock is mainly determined by the balance between new $\mathrm{C}$ input and incorporation into SOM and the decomposition of old $\mathrm{C}$. This has been related to the duration of land use change and to soil depth (Felten \& Emmerling, 2012; Ferrarini et al., 2017a).

The variation of total SOM rates of change in the first 5 years after planting Miscanthus was very high, ranging from -4 to $7 \mathrm{mg} \mathrm{C} \mathrm{ha}^{-1} \mathrm{yr}^{-1}$ [Fig.9b]. A similar finding was reached elsewhere for the first 2-3 years after Miscanthus planting: -6.9 to $7.7 \mathrm{mg} \mathrm{C} \mathrm{ha}^{-1} \mathrm{Yr}^{-1}$ (Zimmerman et al., 2011).

The variation of annual SOM change decreased with time and was negligible after 15 years [Fig.9b]. Miscanthus establishment in the first few years is strongly affected by soil properties and environmental conditions.

This causes changing patterns of $\mathrm{C}$ partitioning within the plant and soil, and influences the SOM content after land-use conversion. Based on the contribution of Miscanthus derived $\mathrm{C}$ to $\mathrm{SOM}$ at different depths 9 and 21 years after land-use change, we simulated the changes in $\mathrm{C}_{4^{-}} \mathrm{C}$ proportions with depth and time as a 3D figure [Fig.9c]. The proportion of $\mathrm{C}_{4}-\mathrm{C}$ in $\mathrm{SOM}$ reached about $80 \%$ in topsoil 20 years after the $\mathrm{C}_{3}-\mathrm{C}_{4}$ vegetation change. The incorporation of $\mathrm{C}_{4}-\mathrm{C}$ in the topsoil was 16 times higher than in the subsoil. 
Zhang et al., (2019) showed that the percentages of the remaining GM C in the soil after one year of decomposition averaged $26 \%$ and $33 \%$ for the above-ground and belowground residues [Fig.10a]. Thus, the 5-yr growth of GM legumes continuously significantly improved the SOC and easily oxidized organic carbon (EOOC) concentrations, as well as the corresponding stocks compared with the original soil at the 0-20 cm depth [Fig.10b].

The cumulative dry matter decomposition rates for the roots of the summer legumes followed the same order with the highest for mung bean $(69 \%)$, the lowest for soybean $(58 \%)$ and intermediate for Huai bean $(68 \%)$. The power model fitted well with the cumulative dry matter decomposition patterns of the GM legumes. The cumulative $\mathrm{C}$ decomposition rates of the GM legumes were the highest in the mung bean followed by the Huai bean and finally the soybean, similar to the pattern of dry matter decomposition.

The per-cent of the mass remaining in the shoots and roots decreased to 23-29\% (on average 26\%) and $28-43 \%$ (on average $33 \%$ ) of the original value in 374 days [Fig.10a]. The mean SOC contents under the SW, MW, and HW systems were $10.5 \%, 12 \%$, and $15.6 \%$ greater (on average 12.7\%) than those in the FW system. As with the SOC, the mean EOOC contents under the MW, SW, and HW systems were $7.8 \%, 9.3 \%$, and $15.3 \%$ greater than those in the FW system. Compared with the initial SOC and EOOC contents at the 0 to $20 \mathrm{~cm}$ depth in 2008, the continuous application of the GM approach for 5-yr significantly increased the corresponding concentrations by $9.0 \%$ and $11.4 \%$ [Fig.10b].

The SOC stocks in the FW system ranged from 14.6 to $21.6 \mathrm{Mg} \mathrm{C} /$ ha with an average of $19.1 \mathrm{Mg} \mathrm{C} / \mathrm{ha}$ and a $\mathrm{CV}$ of $8.2 \%$, while in the GM systems, it ranged from 14.8 to $24.1 \mathrm{Mg}$
$\mathrm{C} / \mathrm{ha}$, with an average of $20.1 \mathrm{Mg} \mathrm{C} / \mathrm{ha}$ and a $\mathrm{CV}$ of $8.3 \%$. The mean EOOC stock in the $\mathrm{GM}$ systems (10.8 $\mathrm{Mg} \mathrm{C/}$ ha) was $3.5 \%$ greater than that in the $\mathrm{FW}(10.5 \mathrm{Mg} \mathrm{C} / \mathrm{ha})$ with a wider range $(9.0-4.0 \mathrm{Mg} \mathrm{C} / \mathrm{ha})$ and a higher variability (9.5\%) [Fig.10b]. The growth of the GM legumes not only efficiently affected the SOC fractions due primarily to the increased $\mathrm{C}$ supply but also increased the $\mathrm{C}$ concentration in the easily oxidized organic matter (EOOM) residues or the EOOM-C as a proportion of the total $\mathrm{C}$ in the soil (Thomazini et al., 2015).

The higher EOOC in the GM systems was probably related to the greater inputs of legume residue and consequently the higher proportion of readily metabolized organic materials, such as sugars, amino acids, and organic acid molecules (Tian et al., 2011).

The SOC stocks measured ranged from 16.9 to 24.1 Mg C/ha under the GM and FW systems in the 0 to $20 \mathrm{~cm}$ soil depth in 2013 and were significantly correlated with the mean annual $\mathrm{C}$ input by the crops [Fig.10c].

The mean turnover time of the SOC at equilibrium was estimated to be 22 years, indicating that the loess soil was not $\mathrm{C}$ saturated and still had the potential for $\mathrm{C}$ sequestration. In general, Huai bean performed better on biomass production, $\mathrm{C}$ accumulation, and soil $\mathrm{C}$ sequestration than mung bean and soybean during the 5 -yr period [Fig.10c].

Soil microbial biomass, the active fraction of soil organic matter which plays a central role in the flow of $\mathrm{C}$ and $\mathrm{N}$ in ecosystems responds rapidly to management practices, and serves as an index of soil fertility.

Adoption of conservation agriculture ultimately resulted in increased soil microbial diversity and activity in the various cropping 
systems more under no-till, than under aggregates are less influenced by type of conventional tillage. However, micro- tillage system.
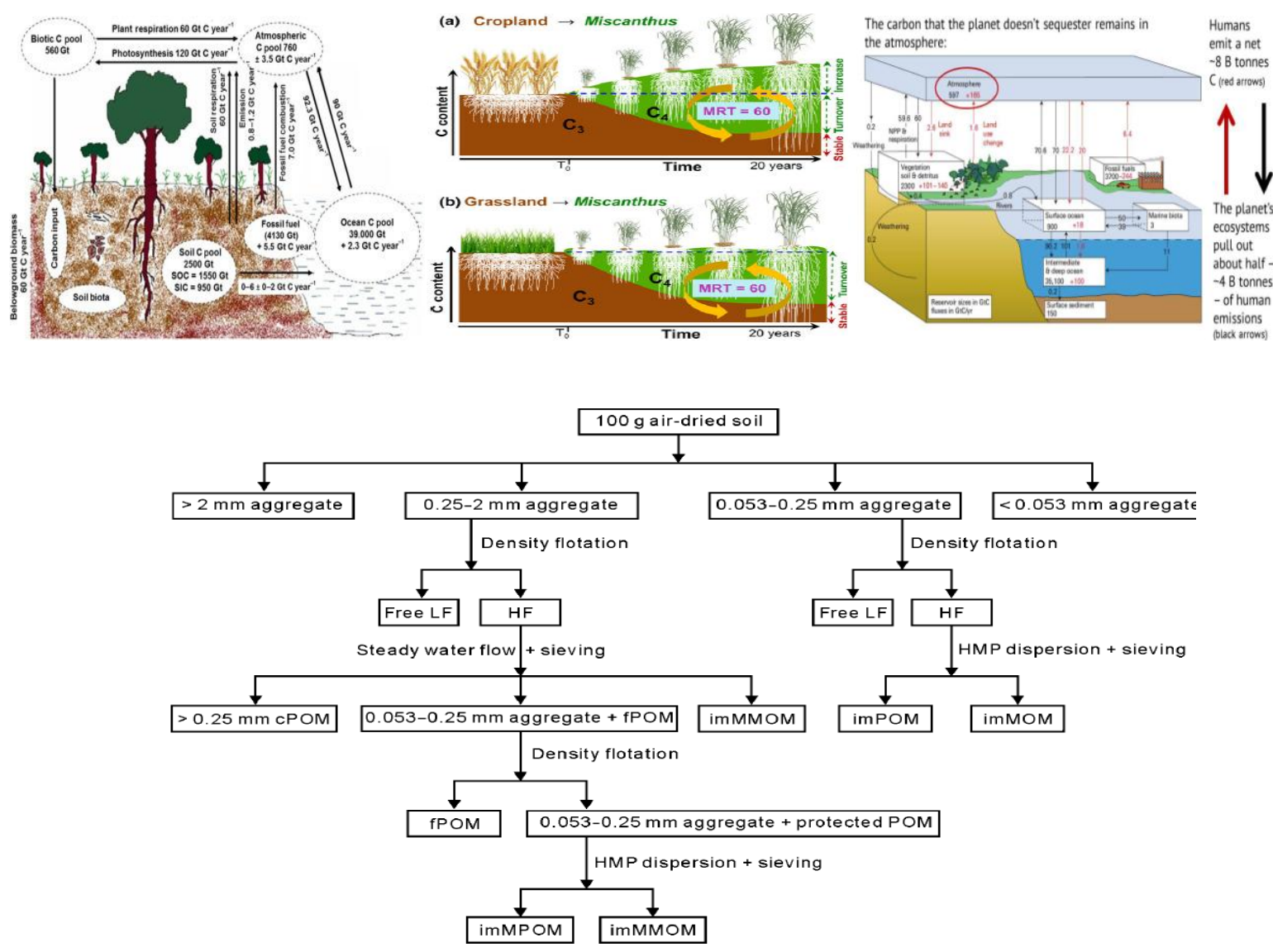

Fig.1(a) Mean weight diameter (MWD) of soil aggregates [Source: Song et al., 2016]

Fig.1(b) Soil aggregate stability (AS) [Source: Song et al., 2016]

Fig.1(c) Influence of treatments on the carbon preservation capacity of different soil aggregates (0-15 and 15-30 cm) [Source: Song et al., 2016]

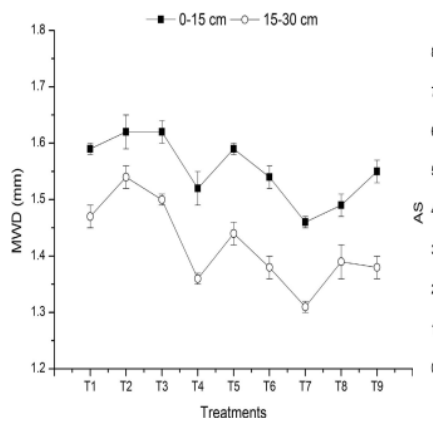

(a)

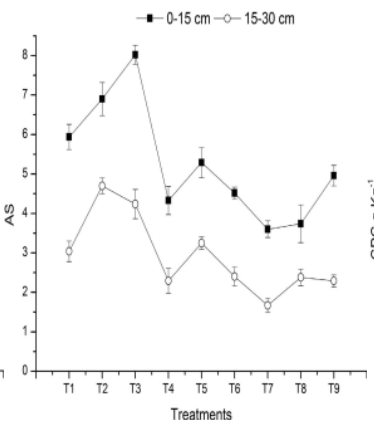

(b)

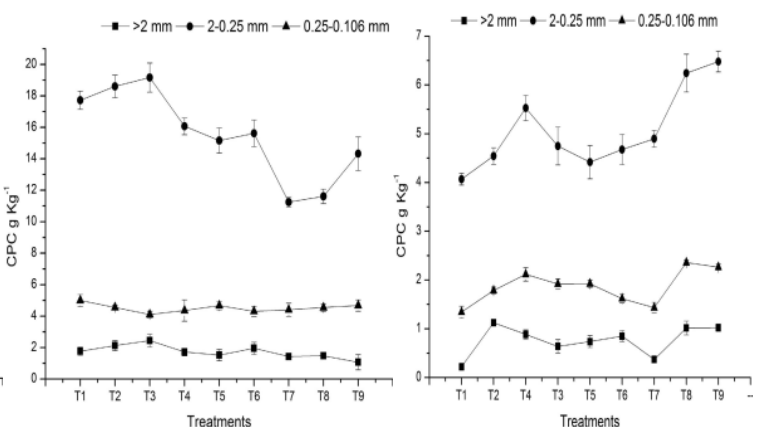

(c) 
Fig.2(a) The organic carbon concentration and mineralization of aggregate soil within 71 days at various soil depths in two restored plantations [Source: Fang et al., 2015]

Fig.2(b) The weighted mean of soil organic carbon mineralized percentage in various aggregates vary with incubation days in two soil depths under two restored plantations [Source: Fang et al., 2015]

Fig.2(c) OC stability influenced by nutrient concentration and aggregate composition in two restored plantations [Source: Fang et al., 2015]

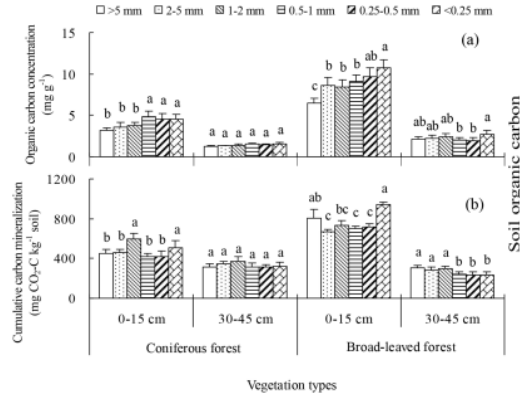

(a)

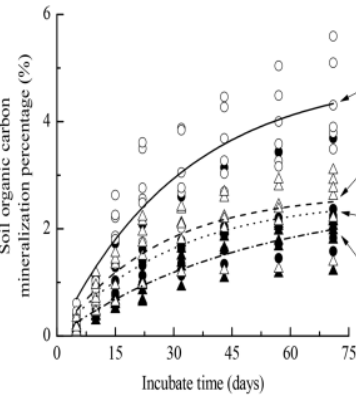

(b)

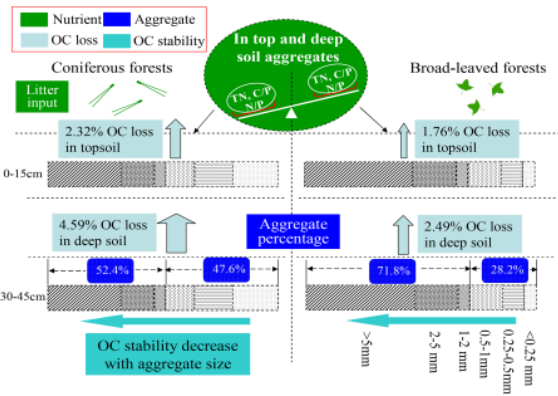

(c)

Fig.3(a) Waterstable aggregatesize distributionin 0-5, 5-10, and 10-20 cm soil depths as 1 influenced by tillage treatments $(\mathrm{MP}-\mathrm{R}$, moldboard plow without corn residue; $\mathrm{MP}+\mathrm{R}$, moldboard plow with corn residue; RT, rotary tillage with corn residue; NT, no-till with corn residue) [Source: Zhang-liu et al., 2013]

Fig.3(b) Sand-free aggregate total C concentrationin0-5, 5-10, and 10-20 cmsoil depthsas 9 influenced by tillage treatments [Source: Zhang-liu et al., 2013]

Fig.3(c) Total soil C stock within aggregate size fractions as influenced by tillage treatments [Source: Zhang-liu et al., 2013]

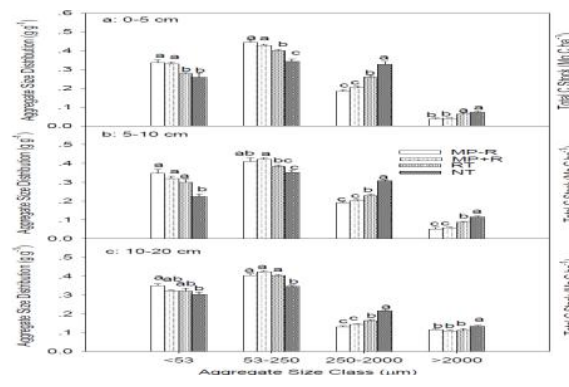

(a)

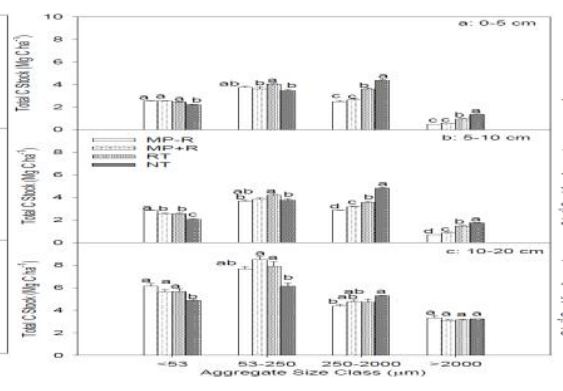

(b)

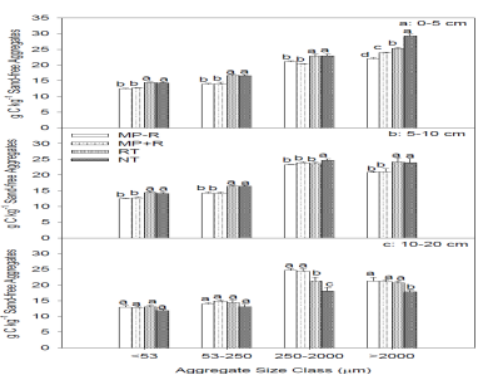

(c) 
Fig.4(a) Values of $C_{\text {mic }}$ and $N_{\text {mic }}$ of spruce, hemlock, and grassland soils: (A) $C_{\text {mic }}$, (B) $N_{\text {mic }}$, (C) $\mathrm{C}_{\text {mid }} / \mathrm{C}_{\text {org }}$ (D) $\mathrm{N}_{\text {mic }} / \mathrm{N}_{\text {tot }}$, and (E) $\mathrm{C}_{\text {mic }} / \mathrm{N}_{\text {mic }}$ [Source: Ravindran and Yang, 2015]

Fig.4(b) Microbial populations (CFU/g dry soil) of spruce, hemlock, and grassland soils: (A) bacteria, (B) actinomycetes, (C) fungi, (D) cellulolytic microbes, (E) phosphate-solubilizing microbes, and (F) nitrogen-fixing microbes [Source: Ravindran and Yang, 2015]

Fig.4(c) Kinetics of wet soil (a) micro-aggregate and (b) macro-aggregates stability decay over time at the top $15 \mathrm{~cm}$ of five tillage systems of a 10 year long-term tillage and crop rotation study

[Source: Al-Kaisi and Yin, 2005]

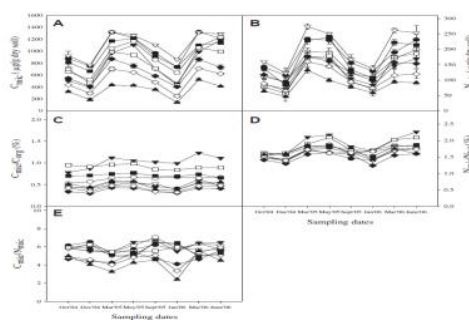

(a)

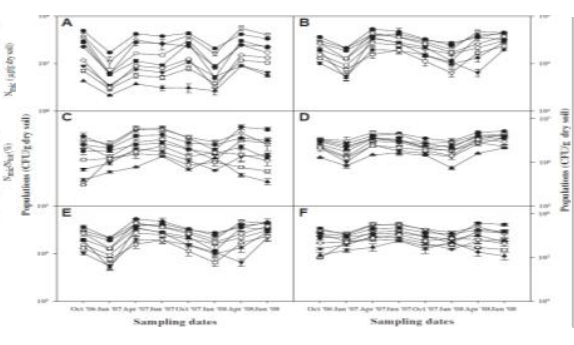

(b)

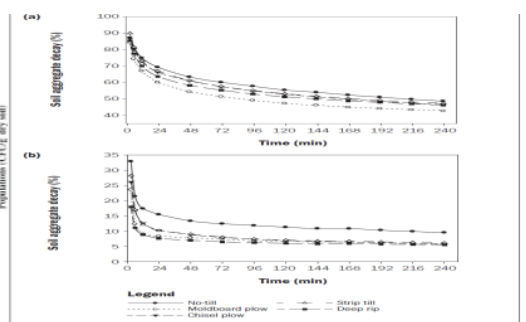

(c)

Fig.5(a) Soil organic carbon stock $\left(\mathrm{Mg} \mathrm{C} \mathrm{ha}^{-1}\right)$ in 0-30 $\mathrm{cm}$ soil depth in different textured soil under conventional (CT) and zero tillage (ZT) practices [Source: Meenakshi, 2016]; Fig. 5(b) Different fractions of organic carbon $(\mathrm{g} / \mathrm{kg})$ at 0-15 and $15-30 \mathrm{~cm}$ soil depths under conventional (CT) and zero (ZT) tillage practice in different textured soils [Source: Meenakshi, 2016]; Fig. 5(c) (a) Soil organic carbon and (b) soil total nitrogen at the top $15 \mathrm{~cm}$ with five tillage systems of a 10 year long-term tillage and corn-soybean rotation. [Source: Al-Kaisi and Yin, 2005].

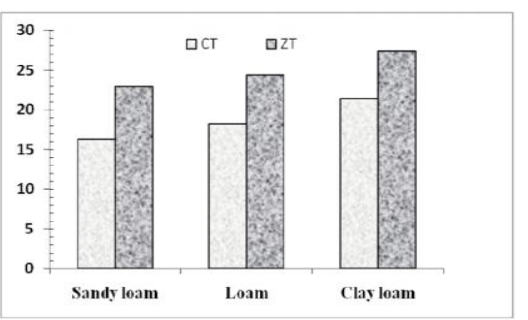

(a)

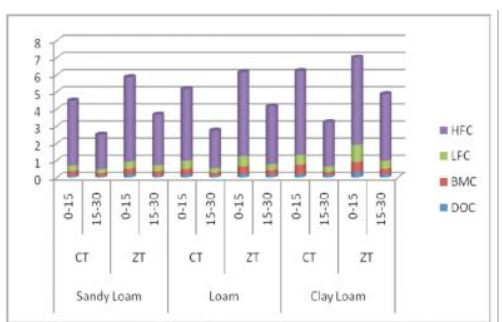

(b)
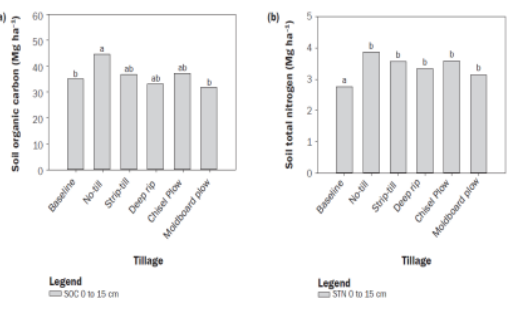

(c) 
Fig. 6(a) Soil aggregate distribution in the 0-5 cm (A), 5-10 $\mathrm{cm}$ (B) and 10-20 $\mathrm{cm}$ (C) depths under different tillage systems. TS, plowing once every year with residue; 2TS, plowing once every two years with residue; 4TS, plowing once every four years with residue; NTS, no plowing all years with residue; $\mathrm{T}$, plowing once every year without residue; $2 \mathrm{~T}$, plowing once every two years without residue; 4T, plowing once every four years without residue; NT, no plowing all years without residue [Source: Xin et al., 2015]; Fig. 6(b) The values of MWD (A) and GMD (B) of soil aggregates in the 0-5, 5-10 and 10-20 cm soil depths under different tillage systems. MWD, mean weight diameter; GMD, geometric mean diameter [Source: Xin et al., 2015]; Fig. 6(c) OC (organic carbon) concentrations in aggregates of 0-5 (A), 5-10 (B) and 10-20 cm (C) soil layers under different tillage systems [Source: Xin et al., 2015]

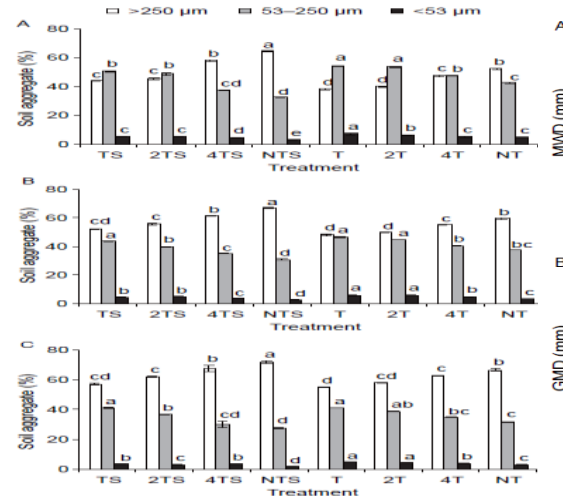

(a)

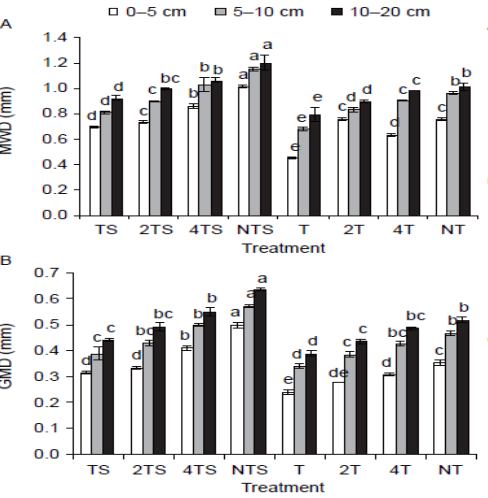

(b)

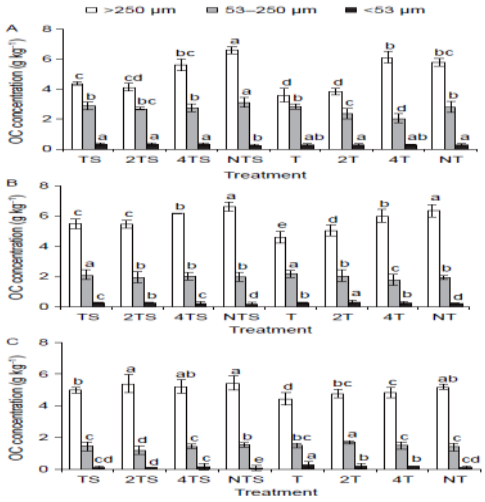

(c)

Fig.7(a) Class distribution of bacterial community compositions in soil samples collected at 0,15, 30 and 60 d during flooded incubation of two paddy soil [Source: Wang et al., 2018]; Fig.7(b) The relationship between different aggregate stability measures and soil functions [Source: Six and Paustian, 2014]; Fig.7(c) Organic C contents and C/N ratios of bulk soil and labile fractions under different fertilization regimes [Source: Li et al., 2018]

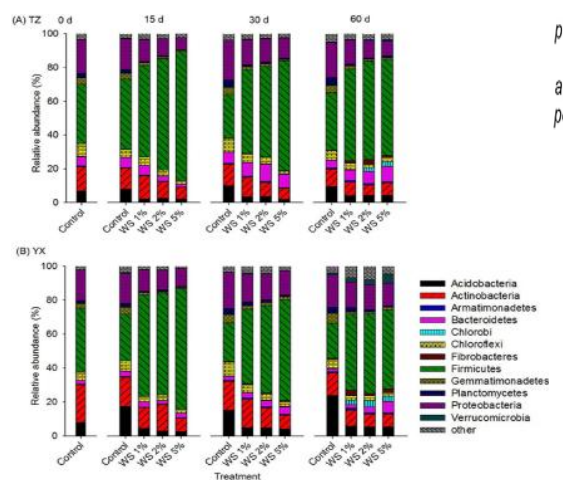

(a)

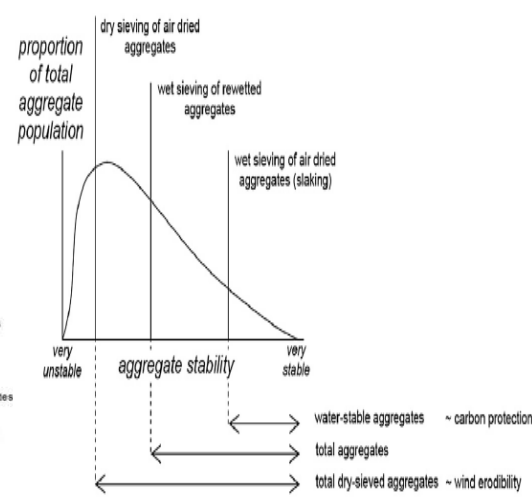

(b)

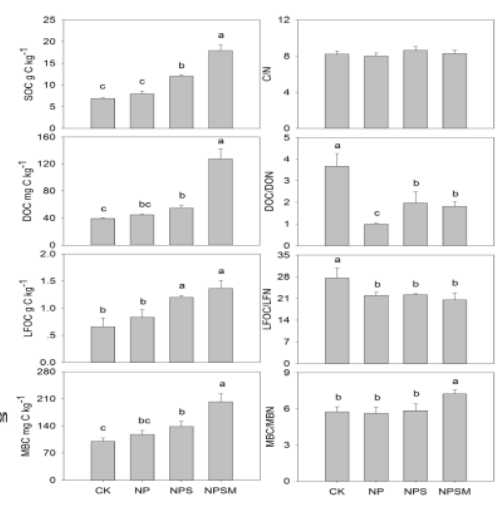

(c) 
Fig.8(a) Abundance of microbial biomarker groups under different fertilization regimes [Source: Li et al., 2018]; Fig.8(b) Responses of soil microbial biomass carbon $\left(\mu \mathrm{gg}^{-1}\right)$ to different tillage and residue manipulation treatments [Source: Kushwaha et al., 2000]; Fig.8(c) Responses of soil microbial biomass nitrogen $\left(\mu \mathrm{gg}^{-1}\right)$ to different tillage and residue manipulation treatments

[Source: Kushwaha et al., 2000]

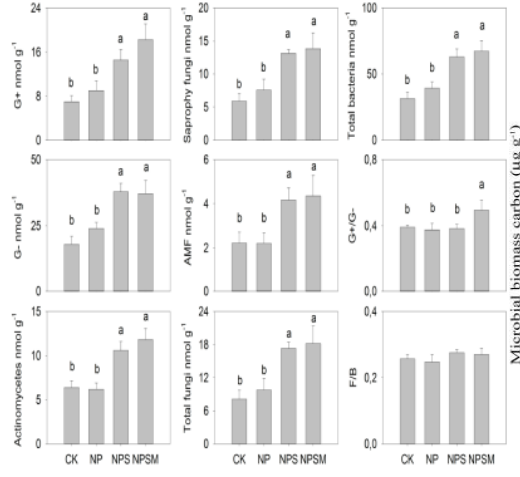

(a)

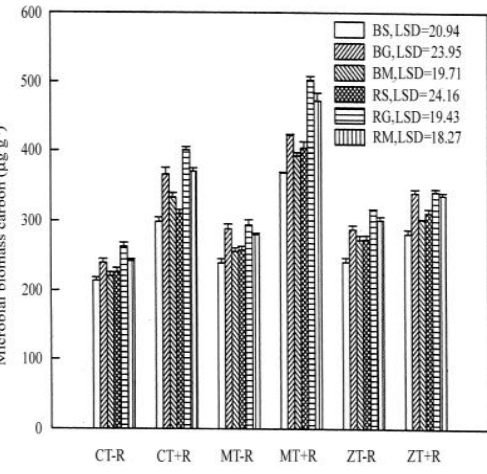

(b)

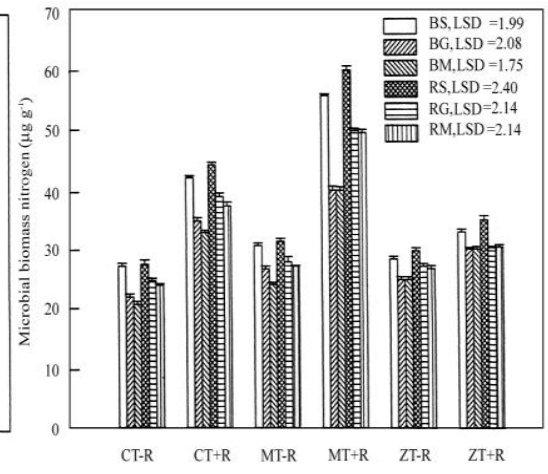

(c)

Fig.9(a) Soil organic matter $\sigma^{13} \mathrm{C}$ values down the soil profile after 9 and 21 years of Miscanthus cultivation [Source: Zang et al., 2017]

Fig.9(b) Total soil organic $\mathrm{C}$ and $\mathrm{C}_{4}-\mathrm{C}$ changes in topsoil [Source: Zang et al., 2017] Fig.9(c) The contribution of Miscanthus $\left(\mathrm{C}_{4}\right)$ derived $\mathrm{C}$ within $100 \mathrm{~cm}$ soil depth over 21 years [Source: Zang et al., 2017]

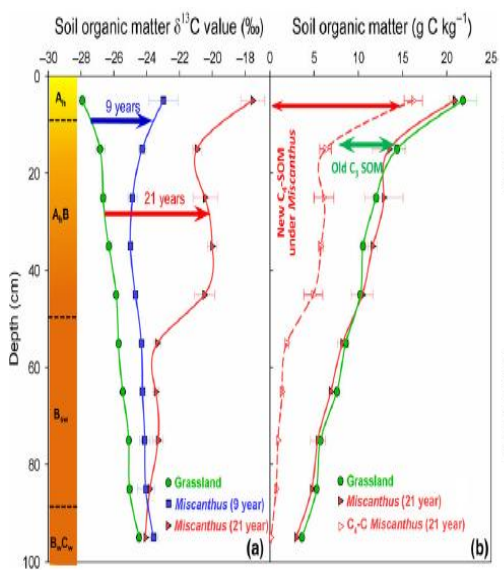

(a)

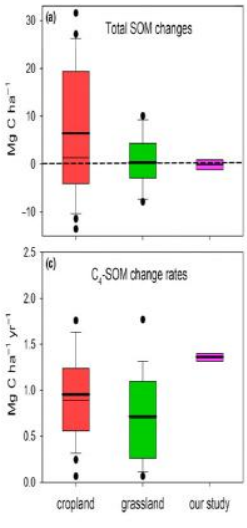

(b)

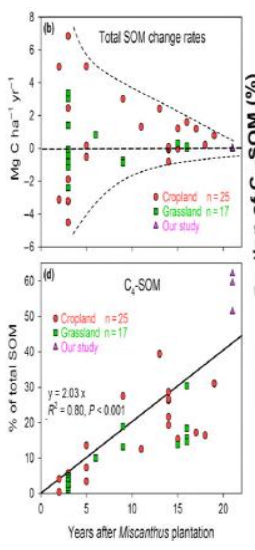

b)

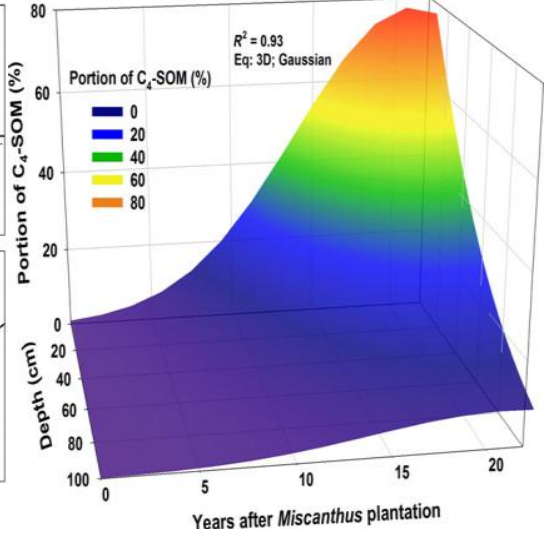

(c) 
Fig.10(a) The cumulative dry matter decomposition rates and carbon release rates of the three GM legumes [Source: Zhang et al., 2019]

Fig.10(b) The SOC (a) and EOOC (b) concentrations, SOC (c) and EOOC (d) stocks in the 0 to $20 \mathrm{~cm}$ depth under the FW and GM systems [Source: Zhang et al., 2019]

Fig.10(c) Relationship between annual C inputs by the crops and the SOC stocks in the 0 to 20 cm depth under the GM and FW systems [Source: Zhang et al., 2019]

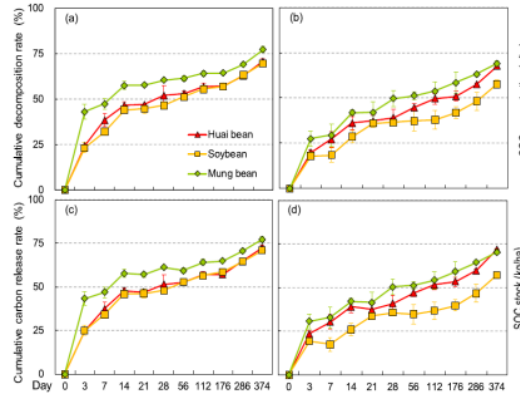

(a)

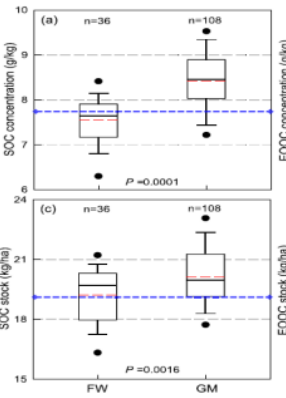

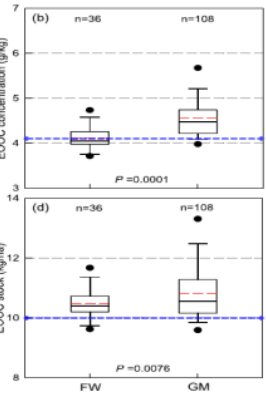

(b)

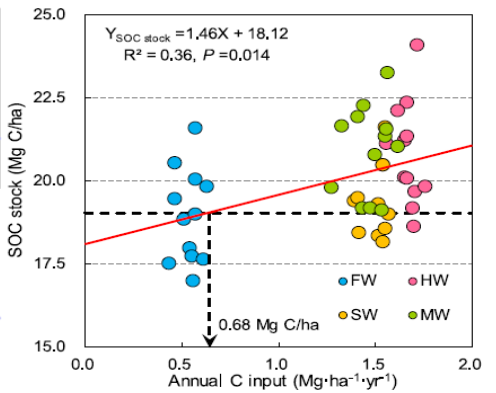

(c)
The increase in SOC content did not only contribute to the increase in aggregate stability, but it caused an increase in soil moisture storage capacity. The value of these findings is highly significant in documenting the long-term stability of aggregate fractions under continuous wet condition and the value of adopting NT to mitigate weather changes and volatility of rain intensities and durations.

The findings also demonstrate the negative effect of conventional tillage not only on SOC decline, but also the weakening of soil aggregate formation and strength under continuous wet conditions, which can lead to other negative effects such as sediment loss and water quality concerns.

The logical consequence is that the microaggregate-within-macro-aggregate fraction shows promising potential for early detection of changes in soil $\mathrm{C}$ arising from changes in management.

A greater percentage of $\mathrm{C}$ was found in all aggregate size classes with the conservation tillage treatments than $\mathrm{CT}$ at the 0 - to $5-\mathrm{cm}$ depth.

At the 10-15-cm depth, however, the highest $\mathrm{C}$ percentages were found in aggregates from the CT and RT treatments, again reflecting a probable lower deposition of $\mathrm{C}$ due to the NT treatment at the lower depth.

Highest levels of soil MBC and MBN (368503 and 38.2-59.7 $\mu \mathrm{g} \mathrm{g}^{-1}$, respectively) were obtained in minimum tillage residue retained (MT‡R) treatment and lowest levels (214-264 and 20.3-27.1 $\mu \mathrm{g} \mathrm{g}^{-1}$, respectively) in conventional tillage residue removed (CT-R, control) treatment. Along with residue retention tillage reduction from conventional to zero increased the levels of MBC and MBN (36-82 and 29-104\% over control, respectively). The proportion of $\mathrm{MBC}$ and MBN in soil organic $\mathrm{C}$ and total $\mathrm{N}$ contents increased significantly in all treatments compared to control.

This increase $(28 \%$ in case of $\mathrm{C}$ and $33 \% \mathrm{~N})$ was maximum in MT $\$ \mathrm{R}$ and minimum $(10 \%$ for $\mathrm{C}$ and $\mathrm{N}$ both) in minimum tillage residue removed (MT-R) treatment. Tillage reduction 
and residue retention both increased the proportion of organic $\mathrm{C}$ and total $\mathrm{N}$ present in soil organic matter as microbial biomass.

Microbial immobilization of available-N during the early phase of crops and its pulsed release later during the period of greater $\mathrm{N}$ demand of crops enhanced the degree of synchronization between crop demand and $\mathrm{N}$ supply. The maximum enhancement effects were recorded in the minimum tillage along with residue retained treatment. Organic N percentages in the aggregates were uniformly greater in all aggregate size classes with the conservation tillage treatments at the 0 - to 5cm depth.

The effects of CA significantly increased abundances of all PLFA-related microbial communities including $\mathrm{G}^{+}$bacteria, $\mathrm{G}^{-}$ bacteria, actinomycetes, saprophytic fungi and AMF. CA also slightly altered the composition of microbial communities.

Furthermore, the application of CA resulted in $53 \%-85 \%$ greater cumulative mineralization of $\mathrm{C}$. Soil labile $\mathrm{C}$ fractions and soil microbial communities predominantly determined the variance in $\mathrm{C}$ mineralization in the current agricultural system. This has to be carefully taken into account when setting realistic and effective goals for long-term soil $\mathrm{C}$ stabilization.

\section{References}

Adesemoye, A.O.; and Kloepper, J.W. 2009.Plant-microbes interactions in enhanced fertilizer-use efficiency. Appl. Microbiol. Biotechnol. 85: 1-12.

Al-Kaisi MM, Douelle A, and Kwaw-Mensah D. 2014. Soil micro-aggregate and macro-aggegate decay over time and soil carbon change as influenced by different tillage systems. J Soil Water Cons. 69(6):574-580.
Bertol I, Barbosa FT, Mafra AL, and Flores MC. 2014. Soil water erosion under different cultivation systems and different fertilization rates and forms over 10 years. Rev Bras Cienc Solo. 38:1918-28.

Bronick CJ, and Lal R. 2005. Soil structure and management: a review. Geodema. 124:3-22.

Cheng-Hua, L., Yan, Y., and Qi, C. 2014. Dynamics of Soil Organic Carbon Fractions and Aggregates in Vegetable Cropping Systems. Pedosphere 24(5): 605-612.

Chivenge, P.P., H.K. Murwira, K.E. Giller, P. Mapfumo, and J. Six. 2007. Long-term tillage and residue management on soil carbon stabilization: Implications for conservation agriculture on contrasting soils. Soil Tillage Res. 94:328-337.

Compant, S.; Clément, C.; and Sessitsch, A. 2010. Plant growth-promoting bacteria in the rhizo- and endosphere of plants: Their role, colonization, mechanisms involved and prospects for utilization. Soil Biol. Biochem. 42:669-678.

Denef K, and Six J. 2005. Clay mineralogy determines the importance of biological versus abiotic processes for macro-aggregate formation and stabilization. Eur J Soil Sci. 56: 469479.

Dou S, Li K, and Guan S. 2011. A review on organic matter in soil aggregates. Acta Pedologica Sinica. 48 (2):412-418

Fang X-M, Chen F-S, Wan S-Z, Yang Q-P, Shi J-M. 2015. Topsoil and Deep Soil Organic Carbon Concentration and Stability Vary with Aggregate Size and Vegetation Type in Subtropical China. PLoS ONE 10(9): e0139380. doi:10.1371/journal.pone.0139380

Felten D, and Emmerling C. 2012. Accumulation of Miscanthus-derived carbon in soils in relation to soil depth and duration of land use under 
commercial farming conditions. $J$. Plant Nutri Soil Sci, 175: 661-670.

Ferrarini A, Fornasier F, Serra P, Ferrari F, Trevisan M, and Amaducci S. 2017a. Impacts of willow and miscanthus bioenergy buffers on biogeochemical $\mathrm{N}$ removal processes along the soilgroundwater continuum. $G C B$ Bioenergy, 9: 246-261.

Fontaine S, Barot S, Barre P, Bdioui N, Mary B, Rumpel C. 2007.Stability of organic carbon in deep soil layers controlled by fresh carbon supply. Nature 450: 277281.

Gale, W.J., C.A. Cambardella, and T.B. Bailey. 2000. Root derived carbon and formation and stabilization of aggregates. Soil Sci Soc Am J. 64:201207.

Guimarães DV, Gonzaga MIS, Silva TO, Silva TL, Dias NS, and Matias MIS. 2013. Soil organic matter pools and carbon fractions in soil under different land uses. Soil Tillage Res. 126:17782.

Hamza MA, and Anderson WK. 2005.Soil compaction in cropping systems: a review of the nature, causes, and possible solutions. Soil Tillage Res 82:121-145.

Hok L, Sá JCM, Boulakia S, Reyes M, Leng $\mathrm{V}$, Kong R, Tivet FE, Briedis C, Hartman D, Ferreira LA, Magno T, and Pheav S. 2015. Short-term conservation agriculture and biomass$\mathrm{C}$ input impacts on soil $\mathrm{C}$ dynamics in a savanna ecosystem in Cambodia. Agr Ecosyst Environ. 214:54-6

Huang DD, Liu SX, Zhang XP, Xu JP, Wu LJ, and Lou YJ. 2012. Constitute and organic carbon distribution of soil aggregates under conservation tillage. J Agro-Environ Sci. 31(8):1560-1565.

Humberto BC, and Rattan L. 2004. Mechanism of carbon sequestration in soil aggregates. Plant Sci 23(6):481-
504.

Idol TW, Pope PE, and Ponder F. 2002. Changes in microbial nitrogen across a 100-year chronosequence of upland hardwood forests. Soil Sci Soc Am J 66:1662-1668.

Joergensen RG, Anderson TH, and Wolters T.1995. Carbon and nitrogen relationships in the microbial biomass of soils in beech (Fagus sylvatica) forests. Biol Fertil Soils 19:141-147.

Kladivko EJ. 2001. Tillage systems and soil ecology. Soil Tillage Res 61:61-76.

Kushwaha,C.P., Tripathi,S.K., and Singh, K.P. 2000. Variations in soil microbial biomass and $\mathrm{N}$ availability due to residue and tillage management in a dry-land rice agro-ecosystem. Soil Tillage Res. 56:153-166.

Lal L. 2009. Soil and world food security. Soil Tillage Res 102:1-4.

Li J, Wu X, Gebremikael MT, Wu H, Cai D, Wang B, et al., (2018) Response of soil organic carbon fractions, microbial community composition and carbon mineralization to high- input fertilizer practices under an intensive agricultural system. PLOS ONE 13(4): e0195144.

Liang, B.C.; MacKenzie, A.F.; Schnitzer, M.; Monreal, C.M.; Voroney, R.P. and Beyaert, R.P. 1998. Managementinduced change in labile soil organic matter under continuous corn in eastern Canadian soils. Biol. Fertil. Soils 26:88-94.

Liang AZ, Yang XM, Zhang XP, Shen Y, Shi XH, Fan RQ, et al., 2009. Short-term impacts of no-tillage on soil organic carbon associated with water-stable aggregates in Black Soil of Northeast China. Scientia Agricultura Sinica. 42(8):2801-2808.

Liu XL, He YQ, Li CL, Jang CL, and Chen PB. 2009. Distribution of soil waterstable aggregates and soil organic $\mathrm{C}, \mathrm{N}$ 
and $\mathrm{P}$ in upland red soil. Acta Ecologica Sinica 46(2):255-262.

Oades JM. 1984. Soil organic matter and structural stability: mechanisms and implications for management. Plant Soil.76:319 \pm 337 .

Paul EA, Clark FE. Soil microbiology and biochemistry. $\quad 2^{\text {nd }}$ ed. London: Academic; 1996. pp. 129-155.

Paul BK, Vanlauwe B, Ayuke F, Gassner A, Hoogmoed M, Hurisso TT, Koala S, Lelei D, Ndabamenye T, Six J, Pulleman MM. 2013. Medium-term impact of tillage and residue management on soil aggregate stability, soil carbon and crop productivity. Agr Ecosyst Environ. 164:14-22.

Ouattara, K., B. Ouattara, G. Nyberg, M.P. Sédogo, and A. Malmer. 2008. Effects of ploughing frequency and compost on soil aggregate stability in a cottonmaize (Gossypium hirsutum-Zea mays) rotation in Burkina Faso. Soil Use Manag 24:19-28,

Ravindran, A., Yang, S.S. 2015. Effects of vegetation type on microbial biomass carbon and nitrogen in subalpine mountain forest soils. $J$ Microbiol Immunol Infe. 48: 362-369

Sainju, U.M., J.D. Jabro, and W.B. Stevens. 2008. Soil carbon dioxide emission and carbon sequestration as influenced by irrigation, tillage, cropping system and nitrogen fertilization. $J$ Environ Quality 37:98-106.

Seben Junior GF, Corá JE, and Lal R. 2014. The effects of land use and soil management on the physical properties of an Oxisol in Southeast Brazil. Rev Bras Cienc Solo. 38:1245-55.

Singh, H., and Singh, K.P. 1993. Effect of residue placement and chemical fertilizer on soil microbial biomass under tropical dryland cultivation. Biol. Fertil. Soils 16: 275-281.
Six J, Elliott ET, and Paustian K. 2000. Soil macro-aggregate turnover and microaggregate formation: a mechanism for $\mathrm{C}$ sequestration under no-tillage agriculture. Soil Biol Biochem. 32:2099-2103.

Six J, Elliott EF, Paustian K, and Doran W. 1998. Aggregation and soil organic matter accumulation in cultivated and native grassland soils. Soil Sci. Soc. Am. J. 62:1367-1377.

Six J, Elliot ET, and Paustian K. 1999. Aggregate and soil organic matter dynamics under conventional and notillage systems. Soil Sci. Soc. Am. J. 63:1350-1358.

Johan Six, J., and Paustian, K. 2014. Aggregate-associated soil organic matter as an ecosystem property and a measurement tool. Soil Biol Biochem. 68:A4-A9.

Song, Ke., Yang, J., Xue, Y., Lv, W., Zheng, X., and Pan, J. 2016. Influence of tillage practices and straw incorporation on soil aggregates, organic carbon, and crop yields in a rice-wheat rotation system. Sci Rep., 6:36602. DOI: 10.1038/srep36602

Thomazini, A., Mendonca, E.S., Souza, J.L., et al., 2015. Impact of organic no-till vegetables systems on soil organic matter in the Atlantic Forest biome. Sci. Hortic. 182:145-155.

Tian, Y., Liu, J., Wang, X., et al., 2011. Carbon mineralization in the soils under different cover crops and residue management in an intensive protected vegetable cultivation. Sci. Hortic. 127: 198-206.

von Lützow M, Kögel-Knabner I, Ekschmitt K, Flessa H, Guggenberger G, Matzner $\mathrm{E}$, et al., 2007. SOM fractionation methods: relevance to functional pools and to stabilization mechanisms. Soil Biol Biochem 39: 2183-2207.

Wang, N., Yu, J.G., Zhao, Y.H., Chang, Z.Z., 
Shi, X.X., Lena Q. Ma, L.Q., and Li, H.B. 2018. Straw enhanced $\mathrm{CO}_{2}$ and $\mathrm{CH}_{4}$ but decreased $\mathrm{N}_{2} \mathrm{O}$ emissions from flooded paddy soils: Changes in microbial community compositions. Atmos Environ. 174:171-179.

Wolschick, N.H., Barbosa,F.T., Bertol, I.B., Bagio, B., and Kaufmann, D.S. 2018. Long-Term Effect of Soil Use and Management on Organic Carbon and Aggregate Stability. Rev Bras Cienc Solo, 42:e0170393.

Xin, S., An-ning, Z., Jia-bao, Z., Wen-liang, Y., Xiu-li, X., and Xian-feng, Z. 2015. Changes in soil organic carbon and aggregate stability after conversion to conservation tillage for seven years in the Huang-Huai-Hai Plain of China. $J$ Integr Agri. 14(6): 1202-1211.

Zang, H., Balgodatskaya, E., Wen, Y., Xu, X., Dyckmans, J., and Kuzyakov, Y. 2017. Carbon sequestration and turnover in soil under the energy crop Miscanthus: repeated ${ }^{13} \mathrm{C}$ natural abundance approach and literature synthesis. $G C B$ Bioenergy doi: 10.1111/gcbb.12485

Zimmerman AR, Gao B, and Ahn MY. 2011. Positive and negative carbon mineralization priming effects among a variety of biochar-amended soils. Soil
Biol Biochem, 43: 1169-1179.

Zhang-liu, D.U., Tu-sheng,R., Chun-sheng, H.U., Qing-zhong, Z., and Humberto, B.C. 2013.

Soil Aggregate Stability and AggregateAssociated Carbon under Different Tillage Systems in the North China Plain. $J$ Integ Agri. doi: 10.1016/S2095-3119(13)60428-1

Zhang, D., Yao, P., Zhao, Na., Cao, W., Zhang, S., Li, Y., Huang, D., Zhai, B., Wang, Z., and Gao, Y. 2019. Building up the soil carbon pool via the cultivation of green manure crops in the Loess Plateau of China. Geoderma 337: 425-433.

Zheng ZC, Wang YD, Li TX, and Yang YM. 2011. Effect of abandoned cropland on stability and distributions of organic carbon in soil aggregates. $J$ Nat Resour. 26(1):119-127.

Zhou H, Lu YZ, and Li BG.2009. Advancement in the study on quantification of soil structure. Acta Ecologica Sinica. 46(3): 501-506.

Zhou P, and Pan GX. 2007. Effect of different long-term fertilization treatments on particulate organic carbon in waterstable aggregates of Paddy Soil. Chinese J Soil Sci. 38(2):256-261.

\section{How to cite this article:}

Rajendra Kumar, R. K. Naresh, Robin Kumar, S. K. Tomar, Amit Kumar, M. Sharath Chandra, Omkar Singh, N. C. Mahajan and Reenu Kumar. 2019. Conservation Tillage Impact on Topsoil and Deep Soil Aggregation and Aggregate Associated Carbon Fractions and Microbial Community Composition in Subtropical India: A Review. Int.J.Curr.Microbiol.App.Sci. 8(10): 283-302. doi: https://doi.org/10.20546/ijcmas.2019.810.030 